\title{
Drivers of increased soil erosion in East Africa's agro-pastoral systems: changing interactions between the social, economic and natural domains
}

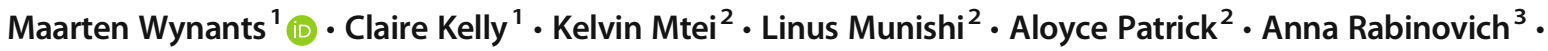 \\ Mona Nasseri ${ }^{4}$ - David Gilvear ${ }^{1}$. Neil Roberts ${ }^{1}$. Pascal Boeckx ${ }^{5}$. Geoff Wilson ${ }^{1} \cdot$ William H. Blake ${ }^{1}$. \\ Patrick Ndakidemi ${ }^{2}$
}

Received: 6 November 2018 / Accepted: 23 May 2019 / Published online: 8 June 2019

(C) The Author(s) 2019

\begin{abstract}
Increased soil erosion is one of the main drivers of land degradation in East Africa's agricultural and pastoral landscapes. This wicked problem is rooted in historic disruptions to co-adapted agro-pastoral systems. Introduction of agricultural growth policies by centralised governance resulted in temporal and spatial scale mismatches with the complex and dynamic East African environment, which subsequently contributed to soil exhaustion, declining fertility and increased soil erosion. Coercive policies of land use, privatisation, sedentarisation, exclusion and marginalisation led to a gradual erosion of the indigenous social and economic structures. Combined with the inability of the new nation-states to provide many of the services necessary for (re)developing the social and economic domains, many communities are lacking key components enabling sustainable adaptation to changing internal and external shocks and pressures. Exemplary is the absence of growth in agricultural productivity and livelihood options outside of agriculture, which prohibits the absorption of an increasing population and pushes communities towards overexploitation of natural resources. This further increases social and economic pressures on ecosystems, locking agro-pastoral systems in a downward spiral of degradation. For the development and implementation of sustainable land management plans to be sustainable, authorities need to take the complex drivers of increased soil erosion into consideration. Examples from sustainable intensification responses to the demands of population increase, demonstrate that the integrity of locally adapted systems needs to be protected, but not isolated, from external pressures. Communities have to increase productivity and diversify their economy by building upon, not abandoning, existing linkages between the social, economic and natural domains. Locally adapted management practices need to be integrated in regional, national and supra-national institutions. A nested political and economic framework, wherein local communities are able to access agricultural technologies and state services, is a key prerequisite towards regional development of sustainable agro-pastoral systems that safeguard soil health, food and livelihood security.
\end{abstract}

Keywords Soil erosion $\cdot$ East Africa $\cdot$ Agro-pastoral systems $\cdot$ Sustainable intensification

Communicated by: Kathleen Hermans

Maarten Wynants

maarten.wynants@plymouth.ac.uk

1 School of Geography, Earth and Environmental Sciences, University of Plymouth, Drake Circus, Plymouth, Devon PL4 8AA, UK

2 Nelson Mandela African Institute of Science and Technology, Arusha, Tanzania

3 School of Psychology, University of Exeter, Exeter, UK

4 Faculty of Ecological Design Thinking, Schumacher College, Totnes, UK

5 Isotope Bioscience Laboratory - ISOFYS, Ghent University, Ghent, Belgium

\section{Introduction}

Soil resources in many agricultural and pastoral landscapes of East Africa's inter-lacustrine countries of Burundi, Kenya, Rwanda, Uganda and Tanzania are rapidly being depleted by increased erosion, contributing to widespread land degradation, which threatens food security, water security and livelihood security in the region (Blaikie and Brookfield 2015; Lal 2001; Oldeman 1992; Pimentel 2006). Multiple environmental studies have pointed to an acceleration of surface and gully erosion and a general overshoot of soil erosion over soil production leading to a decreased agricultural productivity, 
pollution of water bodies and ecosystem degradation. The main cause for this accelerated erosion is often attributed to the loss of permanent vegetation through land use change (Fleitmann et al. 2007; Kiage 2013; Maitima et al. 2009; Wynants et al. 2018). While environmental studies provide the much-needed base to understand soil erosion problems, they fail to explain the socio-economic drivers of unsustainable land use change (Ananda and Herath 2003; Blaikie and Brookfield 2015). The population in East Africa has experienced an exponential growth from an estimated 6-12 million in the 20s (Anderson 1984; Trewartha and Zelinsky 1954), 24 million in 1950, 56 million in 1980s to 173 million in 2017 (UNDESA 2017). However, scapegoating the problem to overpopulation and overexploitation of natural resources lacks understanding of the complex human-environment interactions and can potentially fuel detrimental policies (Blake et al. 2018; Kiage 2013; Lambin et al. 2001).

Soils and ecosystems evolve together through a mutual interdependence on the balance between soil erosion and soil production (Montgomery 2007). Multiple biophysical factors naturally interlink to influence the intensity of soil erosion, but we will classify them in four major groups: (i) slope, (ii) climate, (iii) vegetation and (iv) soil characteristics. East Africa is one of the most active geological areas in the world, which has sculpted the region with a distinct topography. The effects of slope are multiple; however, in general, any neutral movement of soil particles through rain impact or others will be influenced by gravity hence move downward (Morgan 2005; Vanmaercke et al. 2014). More importantly, precipitated water has less time to infiltrate the soil and flowing water will move more rapidly on steeper slopes. This gives rise to higher amount and rapid flow of runoff which subsequently has a higher energy to erode the land (Morgan 2005; Poesen et al. 2003). The effect of climate is closely linked with the rainfall amount and intensity. Most areas in East Africa are characterised by a semi-arid climate with a dry season and one or two rainy seasons. During the rainy season, the rain falls in short but intensive downpours and the rainfall erosivity of these events can be very high (Moore 1979; Nicholson 1996). Coupled to climate is the role of vegetation, which buffers the rainfall and water flow energy through covering of the soil, the anchoring effect of its roots and generally improving the soil structure (Greenway 1987; Thornes 1990). Due to the delayed response of vegetation growth to rainfall, there is nothing to buffer the erosional energy of the first rains. This causes the wash erosion potential to be very high in the beginning of the rainy season (Kirkby 1980). Besides intra-annual seasonality, the East African climate is also characterised by high inter-annual variability, with dry and wet years or periods (Nicholson 1996). The ecosystems are thus not static but in a constant disequilibrium, where concepts of climax vegetation and carrying capacity do not apply. These disequilibrium ecosystems are naturally much more vulnerable to soil erosion due to the discrepancies between stabilising vegetation and rainfall (Kiage 2013; Little 1996; Ngecu and Mathu 1999; Sullivan and Rohde 2002). Differences in soil structure, soil chemistry and soil texture naturally influence the erosion vulnerability of an area (Lal 2001; Morgan 2005). Many soils in semi-arid East Africa are particularly vulnerable to detachment processes because of a low organic matter content and weak aggregate stability. Furthermore, these soils generate more runoff through the high prevalence of crusting and overall weak structural development (Blake et al. 2018; Nishigaki et al. 2017). In short, due to the interaction between a distinct sloped topography, high rainfall erosivity, disequilibrium vegetation and fragile soils, catchments in East Africa naturally have high sediment yields (Vanmaercke et al. 2014; Walling and Webb 1996).

Human societies are an integral part of the balance between soil erosion and soil production. So even though soil erosion is a physical process, its underlying causes are also firmly rooted in the social, economic and institutional environment in which land users make decisions (Ananda and Herath 2003; Blaikie and Brookfield 2015; Boardman et al. 2003). On the most direct level of interaction between anthropogenic and biophysical factors, prime locations and modes of farming in East Africa coincide with areas of high vulnerability. One example is that precipitation and soil fertility are often linked to altitude, with more suitable areas for agriculture in sloped highlands (Kurukulasuriya and Mendelsohn 2008; Trapnell and Griffiths 1960). Moreover, farmers often solely depend on rain for watering their crops, whereby they time the planting during the beginning of the rainy season (Barron et al. 2003; Trærup and Mertz 2011), leaving the fields exposed to the full force of torrential rains (Thornes 1990). However, East Africa's agro-pastoral systems are shaped by millennia of coadaptation, reciprocal influencing and feedback mechanisms between communities and ecosystems. It is argued that agropastoral communities could only persist by developing systems which were able to conserve or improve the soil properties (Berkes et al. 2000a; Gual and Norgaard 2010; Lang and Stump 2017; Tengö and Hammer 2003; Widgren and Sutton 1999). In this review, the drivers of increased erosion rates in East Africa are studied through the lens of the three domains of sustainable development: natural, social and economic (Brundtland 1987; Griggs et al. 2013), and their interactions in complex adaptive agro-pastoral systems as illustrated by Fig. 1 (Berkes et al. 2000b; Gual and Norgaard 2010; Liu et al. 2007). The natural domain can be bluntly described as Earth's life support system (Griggs et al. 2013). In this study, it is specifically used to describe the interlinking of soils and vegetation in ecosystems providing regulatory, supporting and provisioning services to the communities (Costanza et al. 1997). The social domain in agro-pastoral systems is arguably the most complex as it is used as an umbrella term to describe social, cultural and governance structures. In this 
Fig. 1 A schematic representation of East Africa's agro-pastoral systems structured by internal interactions between social, economic and natural domains, which are in turn influenced by external pressures, possibly altering the balance in the system

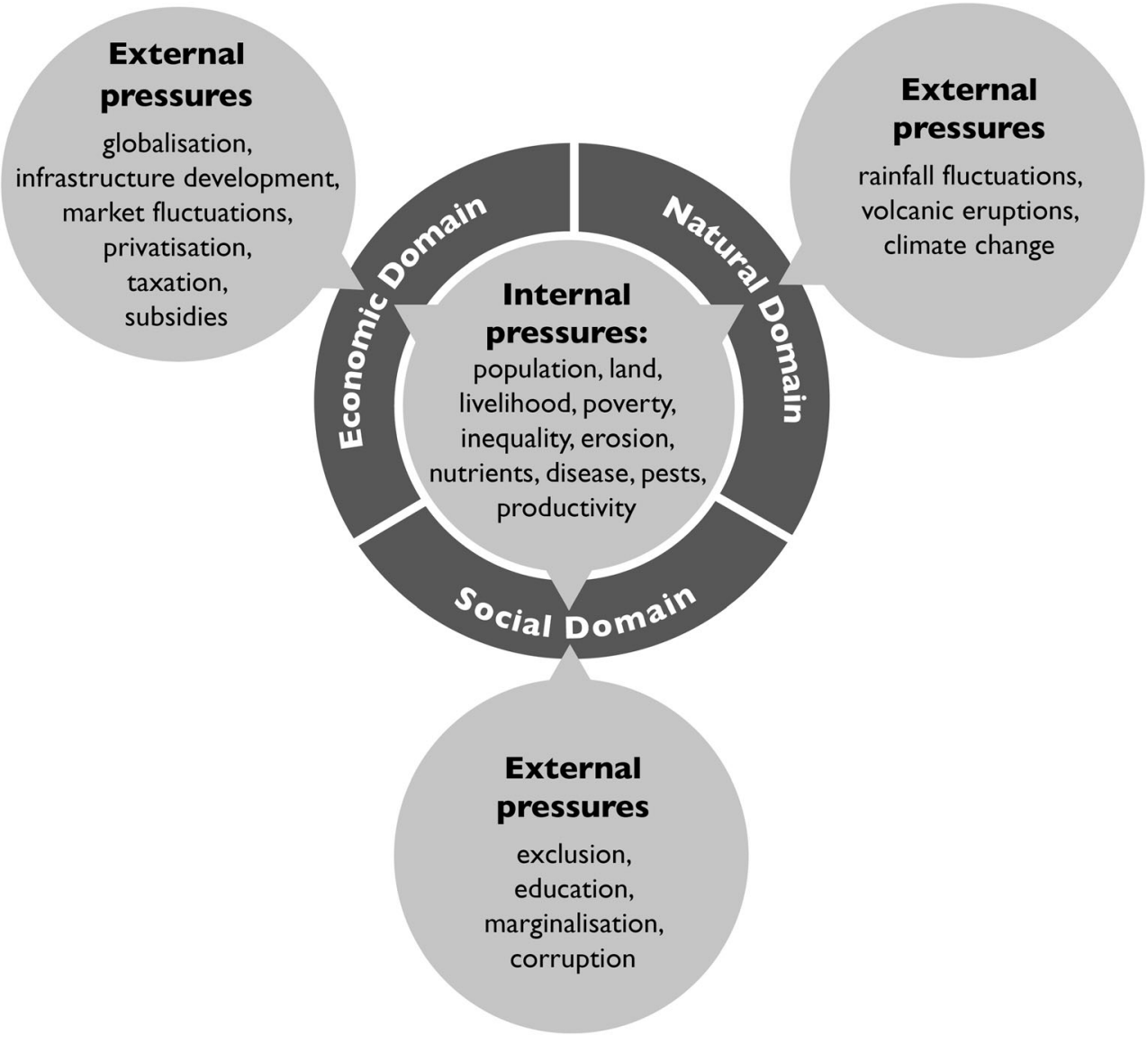

study, it is described as environmental and agronomic knowledge, education, mobility, social networks, culture and norms, but also how and to what degree these factors are embedded in adaptive resource management and governance structures through political representation (Berkes et al. 2000a; Pretty 2003; Rammel et al. 2007). The economic domain constitutes human-produced goods, which in this context of agro-pastoral systems mostly refers to crops and livestock outputs aimed for the market. It thus also represents communities' access to land, fertilisers, seeds and livestock varieties and agricultural technologies needed for the production of those goods. Furthermore, it also comprises infrastructure and access to market structures to exchange the produced goods for capital, which communities can use to increase wellbeing or invest in increasing productivity (Kelly et al. 2015; Tittonell and Giller 2013). The sustainability of agro-pastoral systems is dependent on how these domains interact. Changing internal and external shocks and pressures influence the balance between the natural, economic and social domains. By describing the situation as unsustainable (e.g., the natural domain is degrading), an overview is needed on the historical disruptions to East Africa's agro-pastoral systems leading to current crisis. Additionally, an analysis is needed to illustrate how the three domains currently interact to drive increasing rates of soil erosion (Kelly et al. 2015; Wilson 2012).

\section{Disruption pathways to degradation}

Understanding problems of land degradation driven by increased soil erosion thus not only requires a complete understanding of contemporary social, economic and political drivers, but also the history of disruptions to those factors leading to the current degraded state (Koning and Smaling 2005; Montgomery 2012; Stump 2010). East Africa is a divers region with a complex history, and this review does not attempt to generalise. Instead, we try to give an overview of the disruption history in the region without losing the importance of specific local conditions and outcomes.

\section{Indigenous agro-pastoral systems}

The first European explorers of the savanna plains and tropical highlands of East Africa describe 'pristine' natural environments, where 'primitive' human societies were 'in the defensive' against forces of nature on which they had little impact (Stanley 1889; Thompson 1887; von Höhnel 1894). Contrary to those reports, pre-colonial East African systems were characterised by millennia of reciprocal influencing and coevolution between human societies and ecosystems. Humans had a substantial influence on their environment, which does not mean that pre-colonial agro-pastoral systems never 
collapsed through human or natural disasters (Marchant et al. 2018; Stump 2010; Widgren and Sutton 1999). Additionally, the division of the African population into static tribes or ethnic groups is a colonial construct rather than something inherent to African societies. The tribal structures known today are in reality conglomerates of peoples, who had previously been carriers of different cultural identities (Klopp 2001; Lema 1993; Spear and Waller 1993). Instead, the history of the region is characterised by the spread and changing influence of major African groups, Arabic sultanates, trading networks and slave trade, which influenced land use, politics, culture and economy. Some of these cultures developed into kingdoms and even empires, with dynamic spheres of influence. These population movements and the amalgamation of different peoples have taken place in East Africa since time immemorial (Iliffe 1979; Mamdani 2018; Marchant et al. 2018; Thornton 1980). Agro-pastoral systems in East Africa thus not only had to adapt to changing environmental conditions but also to changing pressures from externally imposed governance systems, migration, trade and culture (Jones 1980; Leach and Mearns 1996; Spear and Waller 1993; Stump 2010). Therefore, we will use the terminology 'indigenous' and specify modes of land use and land tenure when describing communities. What is 'indigenous' is thus not static but a fluid concept of thousands of years of co-evolution between dynamic societies and a dynamic environment (Bruce 1988; Reij et al. 2013).

Most pre-colonial agricultural zones developed in naturally forested areas, but due to the strong dependence on forest ecosystem services, indigenous communities developed a 'conservation ethos', where natural ecosystems were valued for provision, regulating and supporting services. This often led to communal usage and conservation of those ecosystems with strong local controls to safeguard continued services (Conte 1999; Haugerud 1989; Lawi 2002; Tengö and Hammer 2003; Thornton 1980). In response to the challenging East African conditions, farming systems developed in a way to build and sustain productive soils (Lang and Stump 2017; Widgren and Sutton 1999). For example, intercropping in fertile and wet areas, where a permanent and extensive cover with multiple crop types protected the soil from erosion and regenerated the productivity, as well as providing farmers a more divers output secured from crop failures. Farmers also improved and conserved the soil base and water availability by investing labour to build terraces, cut-off drains, contour ploughing, applying manure, mulching, rotating crop types and selecting crop types suitable for the specific location (Reij et al. 2013; Snyder 1996; Tengö and Hammer 2003; Widgren and Sutton 1999). In these areas of permanent production, households usually had customary rights to plots of land, which was transferable to sons (Bruce 1988; MigotAdholla et al. 1991; Snyder 1996). Shifting cultivation was dominant in less fertile areas, where there was a need to shift the location of farm plots in order to regenerate soil fertility naturally by periods of fallow. In these shifting cultivation systems with lower fertility and higher land abundance, indigenous tenure systems leaned more towards communal control but even then, farmers typically had secured use and inheritance rights through investment of labour or capital, even on the fallow lands (Bates 1986; Bruce 1988; Migot-Adholla et al. 1991; Morgan 1969). Only in areas unsuitable for cultivation due to environmental unpredictability, such as the savanna grasslands, complete communal usage of land was beneficial, as communities needed large areas for grazing and mobility to adapt to variable climatic conditions. In these pastoral systems, communities often adapted a nomadic existence following the rains with their herds (Little 1996; Warren 1995). Evidence suggests that these pastoral communities nonetheless developed elaborate management strategies for the communal lands, which were enforced through strict social norms and cultural traditions (Darkoh 1989; Fratkin 1986; Lawi 2002; Migot-Adholla et al. 1991; Niamir-Fuller 2000; Roth 1996). In all cases, social networks were a vital part of indigenous communities to buffer for droughts, labour or capital shortages (Migot-Adholla et al. 1991; Odgaard 2002; Tengö and Hammer 2003; Widgren and Sutton 1999). Additionally, the indigenous land use and tenure systems were not static but adapted to changing conditions, both natural as anthropogenic, from inside or outside the agro-pastoral system (Bruce 1988; Cohen 1980; Migot-Adholla et al. 1991). Historical records suggest that land tenure and land use demonstrated remarkable flexibility in adapting to new farming technologies, climate fluctuations, land opportunities, population increase or methods of exchange long before the colonial period (Bates 1986; Haugerud 1989; Jones 1980; Morgan 1969; Ruthenberg and Jahnke 1985; Snyder 1996). Indigenous agro-pastoral systems in East Africa thus have to be characterised as dynamic points along a continuum depending on the local environmental, social and economic conditions influencing the extent and patchwork constitution of settlements with permanent intercropping and/or shifting cultivation areas, natural or human-created grasslands, primary forest and recovering secondary forest. Even though it is generally accepted now that these early European reports were motivated by racial and political prejudices, they nonetheless formed the justification of the colonial policies of intervention in human-environment relations in East Africa (Coulson 1981; Leach and Mearns 1996; Stump 2010).

\section{The colonial disruption}

The colonial rule subjected all of the inter-lacustrine East African countries from the end of the nineteenth century continuing for the greater part of the twentieth century. While the policies were not static and greatly differed between the territories, they had in all cases major impacts on indigenous 
farming and pastoral systems (Anderson 1984; Blaikie 2016; Kjekshus 1996). The major driver behind these changes was that the colonial state acted to alter human-environmental relationships within western systems of market-led agricultural and resource management. Colonial policies were enforced from a centralised power structure, replacing the more localised indigenous management (Anderson 1984; Smith 1989). While the indigenous land use and land tenure systems were flexible and dynamic, the new colonial rules imposed rigid legal systems distinguishing between private, public and government land (Bruce 1988; Haugerud 1989; Migot-Adholla et al. 1991). Colonial powers also altered indigenous power structures by using chiefs and royals to coerce communities into certain land use, livestock and crop types. Farmers and pastoralists entered the modern economy as producers, but were also forced to pay taxes and buy certain goods and services (Anderson 1984; Coulson 1981; Glazier 1985; Mackenzie 1989; Smith 1989; Tosh 1973). Combined with coerced changes in land use was the large-scale exclusion out of previously communal forest and grazing lands, which were repurposed for private farming, conservation, hunting reserves or forestry. The most productive land was attributed to the state and European settlers, implementing large-scale plantations and monocultures for export. In the process, local smallholder farmers were forced to move to less productive land or work on the plantations (Conte 1999; Kjekshus 1996; Sandford 1919; Sorrenson 1968). Both policies led to a large-scale shift to 'cash crops' of interest to the colonial powers, such as coffee, cotton, rubber and tea, replacing the more diverse selection of food crops (Jones 1980; Kjekshus 1996; Smith 1989). A direct consequence of the centralised agricultural intensification in the diverse and dynamic East African agro-pastoral systems was that areas under years of monocropping regimes and intense grazing were experiencing soil exhaustion, declining fertility and severe erosion (Anderson 1984; Coulson 1981). Indigenous farmers and pastoralists were shunted and confined to marginal areas where they struggled to adapt to the unfamiliar and constricted ecological space, often leading to land degradation and famine (Homewood 1995; Kjekshus 1996; Little et al. 2008; Rutten 1992). Another, indirect, result of this exclusion from previous communally managed pasture and forest land, was a shift from communal land tenure to permanent cultivation as a way to stake claim, where no dispute of ownership was possible. As this process often involved clearing the land of trees and other ecosystem goods deemed valuable for the colonial state, exclusion out of forest and nature reserves thus had the perverse effect of crushing any indigenous impetus towards conservation and often led to increased land degradation outside these conservation centres (Conte 1999; Homewood 1995; Rutten 1992). Perversely, these effects of exclusion were in term used to argue and implement further exclusion and stricter regulations (Anderson 1984; Blaikie 2016; Hodgson 2011; Sendalo 2009).
From an economic development perspective, the instalment of an export-based economy also opened up opportunities to link certain cash-crops to the global market, where farmers could build up economic capital and invest that into better practices. Additionally, the introduction of pesticides, high-yield crop and livestock varieties, mineral fertilisers (post-WW2) and agricultural technologies also offered opportunities to increase the productivity (Boserup 2017; Jones 1980; Migot-Adholla et al. 1991; Ruthenberg 1968; Smith 1989). Whether regions are argued to have developed or have been exploited by colonial rule, the enormous impacts it had on agro-pastoral systems in East Africa cannot be ignored. Historical evidence suggests massive shifts in social organisation, political power balances, agricultural production, land tenure and economic systems, ultimately leading to changing interactions between humans and the environment (Botte 1985a, b; Cochet 2003; Hydén 1980; Kjekshus 1996; Rodney 1972; Smith 1989).

\section{Post-independence disruption}

Many of the post-independence issues regarding unsustainable land management can be attributed to the erosion of indigenous social structures during the colonial period, combined with the sudden release from the strict colonial rules into the chaotic new nation-states as illustrated in Fig. 2a. Good examples of this come from the Usumbara mountains in Tanzania, described by Conte (1999) and Enfors and Gordon (2007), where the process of losing the 'indigenous' conservation ethic during colonial time, combined with increasing population pressures and a sudden release from colonial forest enforcement, led to uncontrolled exploitation and encroachment in the years following independence. As the farmers demand for arable land was a major rallying point during independence struggles, the newly found Tanzanian state (then still known as the republic of Tanganyika, but we refer to Tanzania throughout this paper for simplicity) had difficulties refusing claims for agricultural land. Reports following this conversion of forest to cropland in Usumbara describe rapid decreases in soil quality, increases in sheet erosion and more extreme hydrological conditions with droughts and flash floods. These resulted into rapid degradation of the new farmland, where the farmers often abandoned their newly gained plots after a couple of years (Conte 1999; Lundgren 1978; Lundgren and Lundgren 1979). Other examples are related to soil conservation measures, such as terraces, mulching and tree cover, which were enforced by the colonial government and subsequently formed the basis of 'nationalist' movements in Kenya, Uganda and Tanzania. In the early years after independence, most farmers were not willing to adopt these soil conservation measures because political officials denounced them during 
a)

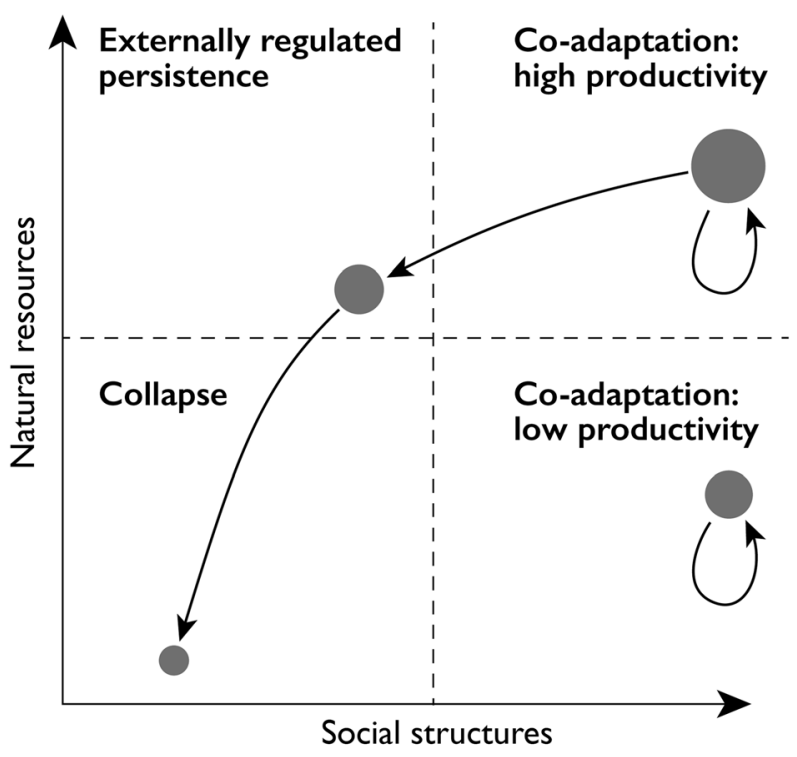

b)

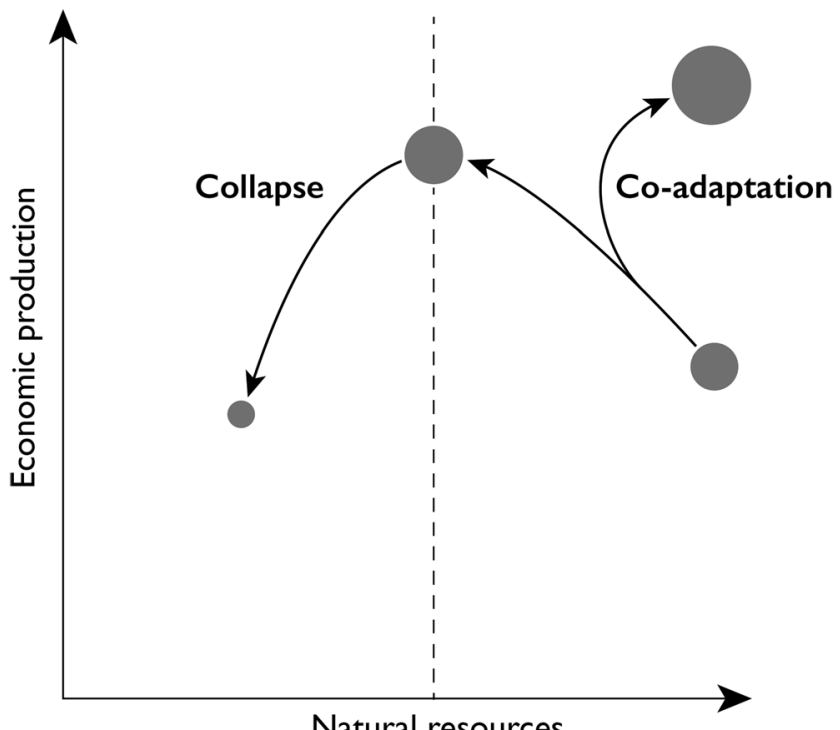

Fig. 2 Conceptual pathways of degradation and co-adaptation in East Africa's agro-pastoral systems. Circle sizes illustrate the benefits generated for the agro-pastoral systems by the interactions of the domains. a Collapse of natural resources is preceded by a gradual erosion of social structures necessary for sustainable resource management. The horizontal dashed line illustrates the ecological tipping point and the vertical dashed line the hypothetical social threshold where after communities lack the social structures to internally manage natural resources and co-adapt to external pressures. Natural differences in productivity and predictability are represented by the different starting points. The circular arrows illustrate the adaptive capacity of systems with a well-developed social domain to higher or sustained high productivity. b A conceptual interaction between the natural and economic domains. If economic production is increased by degrading natural resources, ecosystems will move towards a tipping point, after which both collapse. Communities with a welldeveloped social domain can, however, sustainably intensify production without degrading the natural domain, as illustrated by the co-adaptation arrow independence struggles, which made it difficult to enforce soil conservation by the new nation. As a result, agricultural systems aimed for soil conservation started to break down, leading to systematic degradation and loss of agricultural land (Anderson 1984; Cliffe 1970; Mung'ong'o et al. 1995; Throup 1987).

Fundamentally, post-independence issues regarding unsustainable land management have their roots in the colonial period because the new nation-states were built on colonial laws, policies, borders and western notions of economic growth. Just as the colonial governments, the post-independence centralised policies lacked the complexity and adaptability of local co-evolved agro-pastoral systems, often leading to economic growth strategies which degraded the natural resources as illustrated in Fig. 2b (Hydén 1980; Kjekshus 1977; Lane and Pretty 1990; Ruthenberg 1968; Smith 1989). One of the most interesting cases comes from the Tanzanian 'Ujamaa Vijiji' (villagisation) policy, where people of previously different identities were forced to live in a village nucleus with communal production to build up the Tanzanian national identity and economy (Hydén 1980; Kikula 1997; Kjekshus 1977; Lawi 2007). When enforced these policies disrupted the locally co-adapted agro-pastoral systems greatly. The poor location of many villages regarding water provision, soil productivity and grazing capacity prohibited the instalment of sustainable agricultural practices. Additionally, the forced sedentarisation of previously nomadic pastoralists increased the grazing pressures enormously around the village nucleus. Moreover, lack of any land tenure security halted the production of perennial cash-crops and capital investments in farms. A lot of studies found that due to the complete imbalance between the newly formed 'Ujamaa' communities and the alien environment, systems often spiralled towards land degradation (Coulson 1981; Ellman 1975; Hydén 1980; Kikula 1997; Kjekshus 1977; Lawi 2007; Sendalo 2009). The antipode to 'Ujamaa vijiji' is the effects of liberalisation and globalisation of the markets, which happened in all East African countries but on different timelines and scales (Bryceson 2002). East African governments have continued the exclusion of smallholder farmers and pastoralists from their land, which are being repurposed for game reserves and private agricultural enterprises under the guise of conservation and economic development (Bluwstein et al. 2018; Desta and Coppock 2004; Homewood et al. 2004; Lane and Pretty 1990). Combined with the enforcement of administrative boundaries and sedentarisation policies, this has led to a decrease in the mobility of pastoralist communities, disrupting systems of rotational grazing and adaptability to rainfall fluctuations (Fratkin and Roth 2006; Homewood 1995; Little et al. 2008; Sendalo 2009). This systematic erosion of social and economic structures in agro-pastoral communities through loss of access to land and natural resources, social organisation, knowledge and mobility often led to increased 
pressures on the available resources. Overexploitation of vegetation and soil resources combined with the lack of nutrient input and time to recover has contributed greatly to increased rates of soil erosion and ultimately land degradation (Ruttan and Borgerhoff Mulder 1999). Exactly as during the colonial period, the latter is being used as an argument to intensify policies of exclusion and coercing change (Fratkin and Roth 2006; Hodgson 2011; Homewood 1995; Rutten 1992).

\section{Contemporary drivers of increased soil erosion}

During previous chapter, an overview on the historical disruptions to East Africa's agro-pastoral systems is given, where it is argued that indigenous social and economic structures gradually eroded following external disruptions. This chapter will explore how underdeveloped social and economic domains in East Africa drive the increased rates of soil erosion, where a distinction is made between four major pressures: (i) poverty, (ii) population growth, (iii) governance and political representation and (iv) land rights and land access.

\section{Poverty}

Africa's rural poor are heavily dependent on natural resources for survival, have limited access to capital, fertilisers and technology and thus cannot invest in improved land management. Hence, poverty is a major driver of soil degradation (Boserup 2017; Tittonell and Giller 2013). One example is that poor East African farmers tend to raise row monocrops, such as maize, because of the low investment, quick return and predictable market values, even though the soil is highly susceptible to erosion under these cover types (Barron et al. 2003; Blaikie and Brookfield 2015; Salami et al. 2010). Another example is that most of the rural poor rely on wood and crop residues for building, fodder and fuel. This results in the overharvesting of biomass from natural and agricultural ecosystems, which otherwise would protect the soil from erosion (Barrow 1991; Enfors and Gordon 2007; Hiemstra-van der Horst and Hovorka 2009). In addition to the rural areas, the growing demand for charcoal in East Africa's urban areas is driving degradation of forests and woodland in the entire region (Hofstad 1997). However, what constitutes poverty in East Africa is beyond modern notions of income, expenditures and monetary capital, especially for pastoralist communities. Defining poverty in East Africa's agro-pastoral communities needs better understanding of the changing assets available to households, which can be tangible such as livestock or land, but also non-tangible such as social networks and mobility (Little et al. 2008). Poverty can thus better be described as the lack of assets available to households to obtain a satisfactory standard of living, and is often a result of the underdevelopment of both the social and economic domains in communities. This often forces communities to have an unsustainable reliance on the available natural resources. In next sections, we will explore factors which currently contribute to this underdevelopment.

\section{Population growth}

Linked to poverty are the effects of population growth, which often operate in a tandem. An increasing population results in more mouths to feed, but also more livelihoods to find (Korotayev and Zinkina 2015). A distinction is made between two possible responses to population growth: an unsustainable population-led and a sustainable intensification response. Which of these responses will dominate depends on the local interactions between the natural, social and economic domains in agro-pastoral systems as illustrated by Figs. 1 and 2 (Ananda and Herath 2003; Boserup 2017; Lele et al. 1989). The population-led response locks growing communities into a continuous spiral of increasing exploitation of soil resources, which ultimately prohibits development of sustainable agropastoral systems. Currently, an estimated $75 \%$ of East Africans are dependent on agriculture or pastoralism and without livelihood diversification, the next generation will be forced to find their livelihood in these sectors as well (Jayne et al. 2014; Korotayev and Zinkina 2015). There is ample evidence for the population-led response where increased competition for land following a population boom pushes farmers to smaller and/or unsuitable farming areas and increases grazing pressures on rangelands. This disrupts system of nomadic pastoralism, shifting cultivation and intercropping towards more unsustainable practices with low investment and quick reward (Bryceson 2002; Fratkin and Roth 2006; Kiage 2013; Odgaard 2002; Rufino et al. 2013; Western et al. 2009). In communities with underdeveloped social and economic domains, population increase is thus a major driver of increased rates of soil erosion (Tittonell and Giller 2013). Vice versa, in the sustainable intensification response, population pressure promotes more favourable technological and organisational innovation that not only increases productivity but also preserves other ecosystem services (Ananda and Herath 2003; Bernard and Lux 2017; Boserup 2017). Examples from sustainable intensification responses in African systems demonstrate communities' potential to adapt to increasing population pressure by investing in soil conservation methods, allowing a sustainable increase in productivity and revenues (Barbier 1998; Matlon and Spencer 1984; Tengö and Hammer 2003; Tiffen et al. 1994; Turner et al. 1993). Even though the latter examples of communitydriven sustainable intensification highlight the adaptive capacity when the social and/or economic domains are well developed, it is argued that in areas of East Africa where the population-led response dominates, the only way to escape 
this poverty and population-driven degradation is by external intervention aimed at decreasing human fertility through family planning, compulsory secondary education and rise of the legal marriage age (Korotayev and Zinkina 2015), combined with increasing agricultural productivity, market access and diversifying the livelihood possibilities outside agriculture (Koning and Smaling 2005; Pretty et al. 2006).

\section{Governance and political marginalisation}

This call for external intervention to escape the poverty and population trap leads us to the role of governance, whereby the rate of institutional adaptability relative to environmental dynamics is crucial regarding land and soil management (López 1997). If population-driven environmental change dominates institutional dynamics, then soil erosion will be exacerbated, while if it is the other way around, new institutions that protect the land will emerge (Ananda and Herath 2003; López 1997). This means that strong governments (either local or centralised) have to impose regulations in order to adapt to the increasing pressures without damaging the soil. When this does not happen because of spatial and/or temporal mismatches between policy development and the environmental dynamics, irreversible damage to the land base can occur (López 1997). In that aspect, the centralised governments in most of East Africa's young and developing nationstates have not succeeded to develop and/or implement adequate land management strategies to safeguard the soil base in comparison with the local 'indigenous' systems (Ananda and Herath 2003; Blaikie 2016). However, powerful institutions can also have a perverse effect, when they only focus on increases in productivity and fail to consider the 'damage costs' of certain farming practices. When institutions distort the market by subsidies, tax exemptions, guaranteed prices or protectionist policies, farmers respond to these changing price incentives by changing their crops. Some of these encouraged farming practices or crops may be inherently in high risk in terms of generating runoff and erosion (Boardman et al. 2003; Koning and Smaling 2005; Myers and Kent 2001; Ostrom 2009). Furthermore, this simplistic classification of weak or strong institutions fails to describe the intricacies of the contemporary East African political systems, which are plagued by corruption and the apparent lack of democratic responsibility to provide services that are deemed central to the modern state (Chabal 2013; Hodgson 2011; Klopp 2001). Topdown exploitation of producers by the bureaucratic and political elite creates a negative impetus towards any form of investment in sustainable growth, as the rewards will be taken away (Blaikie 2016; Lopez and Mitra 2000). Moreover, the lack of access to basic state services, such as roads, education, technology and electricity, prohibits communities to develop (Ananda and Herath 2003). Democratic involvement and political representation are thus a key element in protecting or developing strong social and economic structures. Due to the lack of accountability of the political system towards certain communities, some policies are downright exploitative, increasing poverty, inequality and food insecurity (Chabal 2013; Homewood et al. 2004). Even when government intervention has noble intentions, the lack of local involvement in the process of formulating and executing land management strategies may have perverse effects, often leading to management solutions incompatible with the local environment. The political marginalisation of local communities is therefore one of the main drivers of increased rates of soil erosion and environmental degradation in East Africa (Blaikie 2016; Homewood et al. 2004; Klopp 2001).

\section{Land rights and land access}

Following this description of marginalisation, we move to issues regarding land rights and land access in East Africa. The different post-independence nation-states in East Africa have pursued different directions in land policy. For example in Kenya, private property rights were gradually introduced from 1956, while in Tanzania, all land is state-owned, where individuals use land as tenants and the purchase, sale and rental of land are limited within boundaries of the state (Pinckney and Kimuyu 1994). Multiple studies in East Africa have set out to test the effects of these different land tenure systems on agricultural development and inequality but found little or no impact of land titling on investment, nor increased land inequality (Atwood 1990; Bruce 1988; Haugerud 1989; Migot-Adholla et al. 1991; Pinckney and Kimuyu 1994). However, they did found that agricultural communities have held on in different degrees to indigenous land tenure arrangements, which both provide community control, as well as security for investment and have strong impacts on land markets, even when the latter are no longer in effect according to the law (Haugerud 1989; Migot-Adholla et al. 1991; Odgaard 2002; Pinckney and Kimuyu 1994). Due to the introduction of modern land tenure laws combined with the partial conservation of indigenous tenure systems, East African communities currently have a complicated mixture of both indigenous (customary) and formal (modern) land rights (Haugerud 1989; Migot-Adholla et al. 1991; Odgaard 2002; Pinckney and Kimuyu 1994). Under increasing land scarcity, conflicts of land are increasing between individuals who obtained land rights through the different mediums. Often the most powerful and educated people can best navigate the complex maze of bureaucracy and customary rights, leading to increased inequality. In these cases, land conflicts through the presence of two tenure systems decrease land security, which in turn decreases capital and labour investments on farmland. That way, decreasing land security can contribute to unsustainable management of soil resources in agricultural areas (Bluwstein et al. 2018; Odgaard 2002). 
While agricultural systems are under pressure, communal usage of land and resources, which is vital for pastoral communities, is heavily threatened by policies of privatisation and exclusion justified by misconceptions on common land management (Bluwstein et al. 2018; Homewood et al. 2004; Western et al. 2009). Degradation of communal lands is often portrayed as a classic example of 'the tragedy of the commons', where an ever increasing competition between the users of these lands drives its degradation. In these sharedresource systems, individual users act independently according to their own self-interest and thus behave contrary to the common good of all users by depleting that resource through their collective action (Hardin 1968; Ostrom 2000). However, as argued in previous chapter, historical evidence suggests that indigenous pastoral communities developed effective systems of managing common resources in the long-term interest (Ellis and Swift 1988; Niamir-Fuller 2000; Ruttan and Borgerhoff Mulder 1999; Spear and Waller 1993; Sullivan and Rohde 2002). Additionally, there are multiple contemporary examples of successful common land management, if the institutions governing these lands are successful in imposing regulations (Feeny et al. 1990; Ostrom 2000). Pastoral livelihood strategies co-evolved with the unpredictable East African environment where mobility and a sufficient livestock herd acts as a buffer against droughts (Niamir-Fuller 2000; Roth 1996; Spear and Waller 1993). External imposed limits to livestock numbers and mobility thus threatens pastoral livelihood security and food security (Little et al. 2008; Rufino et al. 2013; Ruttan and Borgerhoff Mulder 1999). The problem starts when these indigenous managing systems are disrupted due to internal and external pressures such as population growth, migration, sedentarisation, marginalisation, privatisation and exclusion (Anderson 1984; Fratkin and Roth 2006; Homewood et al. 2004; Western et al. 2009). Therefore, it is argued that when indigenous local arrangements lost influence and/or were replaced by centralised government, the common land tenure regimes gradually converted into open access in which the rule of capture drove each to grab as much as possible before others did. The reality of overgrazing of communal lands can thus best be described as the 'tragedy of open access' rather than 'tragedy of the commons' (Darkoh 1989; Lawi 2002; Migot-Adholla et al. 1991; Roth 1996). Similarly, deforestation following the disappearance of indigenous communal conservation regimes and the collapse or lack of strict state enforcement can be explained as a tragedy of open access (Conte 1999; Enfors and Gordon 2007).

\section{Conclusion}

Even though the pathways to degradation differ a lot in the social, economic and environmental setting, the general pattern is very similar. The thread that links the East African history of land management from pre-colonial times to current conditions can be summarised as the blindness of the modern state, both colonial and post-independence, to the complexities of the locally co-adapted agro-pastoral systems. Key to this is the top-down introduction of interventionist agricultural policies within western notions of economic growth and societal development. Temporal and spatial mismatches between centralised agricultural policies and the divers and dynamic East African environment often directly led to soil exhaustion, decrease of productivity, increased rates of erosion and ultimately the depletion of soil resources. More importantly, indigenous communities were and still are politically marginalised and systematically excluded out of vast areas repurposed for large-scale agriculture, private ranches or conservation under the guise of development. These policies gradually eroded the indigenous social and economic structures and the post-independence East African nation-states are struggling to provide access to key services which are needed to (re)develop them. Impacted communities have difficulties adapting to changing pressures and sustainably manage their natural resources because of the underdevelopment of both social (social networks, political representation, agronomic and ecological knowledge, education, mobility) and economic (land rights and land access, capital, market access, infrastructure, fertilisers, agricultural technologies) domains. A lack of strong social and economic structures impedes communities to adapt to the increasing demands of a booming population. Exemplary to this is the absence of growth in agricultural productivity and livelihood options outside agriculture, which forces communities to degrade and overexploit natural resources. Decreasing natural resources further increases social and economic pressures on ecosystems and this positive feedback locks the system in a pathway to degradation. For the development and implementation of sustainable land management plans to be sustainable, authorities need to take the complex historical and contemporary drivers of increased soil erosion and land degradation into consideration. While modern technologies such as fertilisers and improved crop varieties are essential for increasing agricultural productivity, providing access to modern technologies alone will not solve the current crisis in East Africa. Examples from sustainable intensification responses to population growth highlight the adaptive capacity of communities with a well-developed social domain to increase economic production without compromising continued usage of natural resources. For agro-pastoral systems to follow this sustainable intensification trajectory, the integrity of locally adapted systems, in which management practices and knowledge are embedded, needs to be protected, but not isolated, from external driving forces. Agro-pastoral communities need to adjust to the demands of population increase, commercialisation and modernisation by building upon, not abandoning, existing linkages between the natural, social and economic domains. However, it is not enough to have suitable 
management institutions at local levels if they are not nested in institutions at the regional and national scale. Locally adapted management practices need to be integrated in regional, national and supra-national institutions. A nested political and economic framework allows local communities to access market and governance services, enabling regional development of sustainable agro-pastoral systems that safeguard ecosystem health, food security and livelihood security.

Acknowledgements The authors would like to extend their gratitude to the Nelson Mandela Institution for Science and Technology in Arusha, Tanzania, for their hospitality. Furthermore, the authors would like to thank Mr. Tim Absalom from the GeoMapping unit of the University of Plymouth for his assistance in designing the figures. Finally, the authors would like to thank the reviewers for the constructive criticism and suggestions, which improved the quality of the paper greatly.

Funding information This work was carried out as part of a $\mathrm{PhD}$ project funded by the University of Plymouth with support from the Research Council UK Global Challenges Research Fund (GCRF) grant NE/ P015603/1 and UK Natural Environment Research Council Grant NE/ R009309/1.

Open Access This article is distributed under the terms of the Creative Commons Attribution 4.0 International License (http:// creativecommons.org/licenses/by/4.0/), which permits unrestricted use, distribution, and reproduction in any medium, provided you give appropriate credit to the original author(s) and the source, provide a link to the Creative Commons license, and indicate if changes were made.

\section{References}

Ananda J, Herath G (2003) Soil erosion in developing countries: a socioeconomic appraisal. J Environ Manag 68:343-353. https://doi.org/ 10.1016/S0301-4797(03)00082-3

Anderson D (1984) Depression, dust bowl, demography, and drought: the colonial state and soil conservation in East Africa during the 1930s. Afr Aff 83:321-343 https://www.jstor.org/stable/722351. Accessed 11 June 2018

Atwood DA (1990) Land registration in Africa: the impact on agricultural production. World Dev 18:659-671. https://doi.org/10.1016/0305750X(90)90016-Q

Barbier B (1998) Induced innovation and land degradation: results from a bioeconomic model of a village in West Africa. Agric Econ 19:1525. https://doi.org/10.1016/S0169-5150(98)00052-8

Barron J, Rockström J, Gichuki F, Hatibu N (2003) Dry spell analysis and maize yields for two semi-arid locations in east Africa. Agric For Meteorol 117:23-37. https://doi.org/10.1016/S0168-1923(03) 00037-6

Barrow CJ (1991) Land degradation: development and breakdown of terrestrial environments. Cambridge University Press, Cambridge

Bates R (1986) Some contemporary orthodoxies in the study of agrarian change. In: Kohli A (ed) The state and development in the third world. Princeton University press, pp 67-87

Berkes F, Colding J, Folke C (2000a) Rediscovery of traditional ecological knowledge as adaptive management. Ecol Appl 10:1251-1262. https:// doi.org/10.1890/1051-0761(2000)010[1251:ROTEKA]2.0.CO;2

Berkes F, Folke C, Colding J (2000b) Linking social and ecological systems: management practices and social mechanisms for building resilience vol 1. Cambridge University Press, Cambridge
Bernard B, Lux A (2017) How to feed the world sustainably: an overview of the discourse on agroecology and sustainable intensification. Reg Environ Chang 17:1279-1290. https://doi.org/10.1007/s10113-0161027-y

Blaikie P (2016) The political economy of soil erosion in developing countries. Routledge, London

Blaikie P, Brookfield H (2015) Land degradation and society. Routledge, London

Blake WH, Rabinovich A, Wynants M, Kelly C, Nasseri M, Ngondya I, Patrick A, Mtei K, Munishi L, Boeckx P., Navas A, Smith HG, Gilvear D, Wilson G, Roberts N, Ndakidemi P (2018) Soil erosion in East Africa: an interdisciplinary approach to realising pastoral land management change. Environ Res Lett: 124014. https://doi. org/10.1088/1748-9326/aaea8b

Bluwstein J, Lund JF, Askew K, Stein H, Noe C, Odgaard R, Maganga F, Engström L (2018) Between dependence and deprivation: the interlocking nature of land alienation in Tanzania. J Agrar Chang 18:806-830. https://doi.org/10.1111/joac. 12271

Boardman J, Poesen J, Evans R (2003) Socio-economic factors in soil erosion and conservation. Environ Sci Pol 6:1-6. https://doi.org/10. 1016/S1462-9011(02)00120-X

Boserup E (2017) The conditions of agricultural growth: the economics of agrarian change under population pressure. Routledge, New York

Botte R (1985a) Rwanda and Burundi, 1889-1930: chronology of a slow assassination, part 1. Int J Afr Hist Stud 18:53-91. https://doi.org/10. $2307 / 217974$

Botte R (1985b) Rwanda and Burundi, 1889-1930: chronology of a slow assassination, part 2. Int J Afr Hist Stud 18:289-314. https://doi.org/ $10.2307 / 217744$

Bruce JW (1988) A perspective on indigenous land tenure systems and land concentration. Land and society in contemporary, Africa, pp 23-52

Brundtland G (1987) Report of the 1987 World Commission on Environment and Development: Our Common Future. United Nations, Oslo, vol 1, p 59

Bryceson DF (2002) The scramble in Africa: reorienting rural livelihoods. World Dev:30, 725-739. https://doi.org/10.1016/S0305$750 \mathrm{X}(02) 00006-2$

Chabal P (2013) Africa: the politics of suffering and smiling. Zed Books Ltd., London

Cliffe LR (1970) Nationalism and the reaction to enforced agricultural change in Tanzania during the colonial period. Taamuli 1:3-15

Cochet H (2003) A half century of Agrarian crisis in Burundi (18901945): the incapacity of the colonial administration in managing the Agrarian crisis of the late eighteen-hundreds. Afr Econ Hist 31:19-42. https://doi.org/10.2307/3601945

Cohen JM (1980) Land tenure and rural development in Africa. Holt Saunders Ltd., New York

Conte CA (1999) The forest becomes desert: forest use and environmental change in Tanzania's West Usambara mountains. Land Degrad Dev 10:291-309. https://doi.org/10.1002/(SICI)1099145X(199907/08)10:4<291::AID-LDR363>3.0.CO;2-W

Costanza R, d'Arge R, de Groot R, Farber S, Grasso M, Hannon B, Limburg K, Naeem S, O’Neill RV, Paruelo J, Raskin RG, Sutton $\mathrm{P}$, van den Belt M (1997) The value of the world's ecosystem services and natural capital nature 387:253 https://doi.org/10.1038/ $387253 \mathrm{a} 0$

Coulson A (1981) Agricultural policies in mainland Tanzania, 1946-76. In: Heyer J, Roberts P, Williams G (eds) Rural development in tropical Africa. Palgrave Macmillan, London, pp 52-89

Darkoh MK (1989) Desertification in Africa. Journal of Eastern African Research \& Development 19:1-50 https://www.jstor.org/stable/ 24325608

Desta S, Coppock DL (2004) Pastoralism under pressure: tracking system change in southern Ethiopia. Hum Ecol 32:465-486. https://doi.org/ 10.1023/B:HUEC.0000043516.56037.6b 
Ellis JE, Swift DM (1988) Stability of African pastoral ecosystems: alternate paradigms and implications for development. J Range Manage 41: 450-459 https://journals.uair.arizona.edu/index.php/jrm/article/ download/8307/7919

Ellman A (1975) Development of Ujamaa policy in Tanzania in rural cooperation in Tanzania (edited by Cliffe and Lawrence). Tanzania Publishing House, Dar es Salaam

Enfors E, Gordon L (2007) Analysing resilience in dryland agro-ecosystems: a case study of the Makanya catchment in Tanzania over the past 50 years. Land Degrad Dev 18:680-696. https://doi.org/10. 1002/ldr.807

Feeny D, Berkes F, McCay BJ, Acheson JM (1990) The tragedy of the commons: twenty-two years later. Hum Ecol 18:1-19 https://doi. org/10.1007/BF00889070

Fleitmann D, Dunbar RB, McCulloch M, Mudelsee M, Vuille M, McClanahan TR, Cole JE, Eggins S (2007) East African soil erosion recorded in a 300 year old coral colony from Kenya. Geophys Res Lett 34: L04401. https://doi.org/10.1029/2006GL028525

Fratkin E (1986) Stability and resilience in East African pastoralism: the Rendille and the Ariaal of northern Kenya. Hum Ecol 14:269-286. https://doi.org/10.1007/BF00889031

Fratkin E, Roth EA (2006) As pastoralists settle: social, health, and economic consequences of the pastoral sedentarization in Marsabit District, Kenya vol 1. Kluwer Academic Publishers, New York and London

Glazier J (1985) Land and the uses of tradition among the Mbeere of Kenya. University Press of America, Lanham

Greenway DR (1987) Vegetation and slope stability. In: Anderson MG, Richards KS (eds) Slope stability: geotechnical engineering and geomorphology. John Wiley \& Sons, Chichester, pp 187-230

Griggs D et al (2013) Policy: sustainable development goals for people and planet. Nature 495:305. https://doi.org/10.1038/495305a

Gual MA, Norgaard RB (2010) Bridging ecological and social systems coevolution: a review and proposal. Ecol Econ 69:707-717. https:// doi.org/10.1016/j.ecolecon.2008.07.020

Hardin G (1968) The tragedy of the commons. Science 162:1243-1248. https://doi.org/10.1126/science.162.3859.1243

Haugerud A (1989) Land tenure and agrarian change in Kenya. Africa 59: 61-90. https://doi.org/10.2307/1160764

Hiemstra-van der Horst G, Hovorka AJ (2009) Fuelwood: the "other" renewable energy source for Africa? Biomass Bioenergy 33:16051616. https://doi.org/10.1016/j.biombioe.2009.08.007

Hodgson DL (2011) Being Maasai, becoming indigenous: postcolonial politics in a neoliberal world. Indiana University press, Bloomington

Hofstad O (1997) Woodland deforestation by charcoal supply to Dar es Salaam. J Environ Econ Manag 33:17-32

von Höhnel LR (1894) Discovery of Lakes Rudolf and Stefanie: a narrative of count Samuel Teleki's exploring \& hunting expedition in Eastern Equatorial Africa in 1887 \& 1888 vol 2. Longmans, Green and Co, London

Homewood K (1995) Development, demarcation and ecological outcomes in Maasailand. Africa 65:331-350. https://doi.org/10.2307/ 1161050

Homewood K, Coast E, Thompson M (2004) In-migrants and exclusion in East African rangelands: access, tenure and conflict. Africa 74: 567-610. https://doi.org/10.3366/afr.2004.74.4.567

Hydén G (1980) Beyond Ujamaa in Tanzania: underdevelopment and an uncaptured peasantry. University of California Press, Berkeley and Los Angeles, California

Iliffe J (1979) A modern history of Tanganyika. Cambridge University Press, Cambridge

Jayne TS, Chapoto A, Sitko N, Nkonde C, Muyanga M, Chamberlin J (2014) Is the scramble for land in Africa foreclosing a smallholder agricultural expansion strategy. J Int Aff 67:35-53. https://www. jstor.org/stable/24461734. Accessed 13 June 2018
Jones WO (1980) Agricultural trade within tropical Africa: historical background. In: Bates RH, Lofchie MF (eds) Agricultural development in Africa: issues of public policy, pp 10-45, Praeger Scientific, Westport.

Kelly C, Ferrara A, Wilson GA, Ripullone F, Nolè A, Harmer N, Salvati L (2015) Community resilience and land degradation in forest and shrubland socio-ecological systems: evidence from Gorgoglione, Basilicata, Italy. Land Use Policy 46:11-20. https://doi.org/10. 1016/j.landusepol.2015.01.026

Kiage LM (2013) Perspectives on the assumed causes of land degradation in the rangelands of Sub-Saharan Africa. Prog Phys Geogr 37:664 684. https://doi.org/10.1177/0309133313492543

Kikula IS (1997) Policy implications on environment: the case of villagisation in Tanzania. Nordic Africa Institute, Uppsala

Kirkby MJ (1980) The problem. In: Kirkby MJM, R.P.C. (eds) Soil erosion. Wiley, Chichester, pp 1-16

Kjekshus H (1977) The Tanzanian villagization policy: implementational lessons and ecological dimensions. Canadian Journal of African Studies/La Revue canadienne des études africaines 11:269-282. https://doi.org/10.1080/00083968.1977.10803774

Kjekshus H (1996) Ecology control \& economic development in East African history: the case of Tanganyika. Ohio University Press, Athens, pp 1850-1950

Klopp JM (2001) "Ethnic clashes" and winning elections: the case of Kenya's electoral despotism. Can J Afr Stud 35:473-517. https:// doi.org/10.1080/00083968.2001.10751230

Koning N, Smaling E (2005) Environmental crisis or 'lie of the land'? The debate on soil degradation in Africa. Land Use Policy 22:3-11. https://doi.org/10.1016/j.landusepol.2003.08.003

Korotayev A, Zinkina J (2015) East Africa in the Malthusian trap? J Dev Soc 31:385-420. https://doi.org/10.1177/0169796x15590322

Kurukulasuriya P, Mendelsohn RO (2008) How will climate change shift agro-ecological zones and impact African agriculture? The World Bank Development Research Group, Washington D.C. https://doi. org/10.1596/1813-9450-4717

Lal R (2001) Soil degradation by erosion. Land Degrad Dev 12:519-539. https://doi.org/10.1002/ldr.472

Lambin EF, Turner BL, Geist HJ, Agbola SB, Angelsen A, Bruce JW, Coomes OT, Dirzo R, Fischer G, Folke C, George PS, Homewood $\mathrm{K}$, Imbernon J, Leemans R, Li X, Moran EF, Mortimore M, Ramakrishnan PS, Richards JF, Skånes H, Steffen W, Stone GD, Svedin U, Veldkamp TA, Vogel C, Xu J (2001) The causes of landuse and land-cover change: moving beyond the myths. Glob Environ Chang 11:261-269. https://doi.org/10.1016/S09593780(01)00007-3

Lane CR, Pretty JN (1990) Displaced pastoralists and transferred wheat technology in Tanzania, vol 20. IIED, International Institute for Environment and Development, London

Lang C, Stump D (2017) Geoarchaeological evidence for the construction, irrigation, cultivation, and resilience of 15 th- 18 th century AD terraced landscape at Engaruka, Tanzania. Quat Res 88:382-399. https://doi.org/10.1017/qua.2017.54

Lawi YQ (2002) May the spider web blind witches and wild animals: local knowledge and the political ecology of natural resource use in the Iraqwland, Tanzania, 1900-1985. Leiden University

Lawi YQ (2007) Tanzania's operation Vijiji and local ecological consciousness: the case of Eastern Iraqwland, 1974-1976. J Afr Hist 48:69-93. https://doi.org/10.1017/S0021853707002526

Leach M, Mearns R (1996) The lie of the land: challenging received wisdom on the African environment. International African institute, London. p240

Lele V et al (1989) Population pressure the environment and agricultural intensification. Variations on the Boserup hypothesis vol GTZ-884. The World Bank, Washington, D.C

Lema A (1993) Africa divided: the creation of "ethnic groups" vol. Lund University Press, Lund, p 6 
Little PD (1996) Pastoralism, biodiversity, and the shaping of savanna landscapes in East Africa. Africa 66:37-51. https://doi.org/10.2307/ 1161510

Little PD, McPeak J, Barrett CB, Kristjanson P (2008) Challenging orthodoxies: understanding poverty in pastoral areas of East Africa. Dev Chang 39:587-611

Liu J, Dietz T, Carpenter SR, Alberti M, Folke C, Moran E, Pell AN, Deadman P, Kratz T, Lubchenco J, Ostrom E, Ouyang Z, Provencher W, Redman CL, Schneider SH, Taylor WW (2007) Complexity of coupled human and natural systems. Science 317 : 1513-1516. https://doi.org/10.1126/science.1144004

López R (1997) Where development can or cannot go: the role of poverty-environment linkages. The World Bank, Washington D.C.

Lopez R, Mitra S (2000) Corruption, pollution, and the Kuznets environment curve. J Environ Econ Manag 40:137-150. https://doi.org/10. 1006/jeem.1999.1107

Lundgren B (1978) Soil conditions and nutrient cycling under natural and plantation forests in Tanzanian highlands. Swedish University of Agricultural Sciences, Uppsala

Lundgren L, Lundgren B (1979) Rainfall, interception and evaporation in the Mazumbai forest reserve, West Usambara Mts., Tanzania and their importance in the assessment of land potential. Geogr Ann, Ser A 61:157-178. https://doi.org/10.1080/04353676.1979.11879988

Mackenzie F (1989) Land and territory: the interface between two systems of land tenure, Murang'a district, Kenya. Africa 59:91-109. https://doi.org/10.2307/1160765

Maitima JM, Mugatha SM, Reid RS, Gachimbi LN, Majule A, Lyaruu H, Pomery D, Mathai S., Mugisha S (2009) The linkages between land use change, land degradation and biodiversity across East Africa. Afr J Environ Sci Technol 3: 310-325.

Mamdani M (2018) Citizen and subject: contemporary Africa and the legacy of late colonialism. Princeton University press, Princeton

Marchant R, Richer S, Boles O, Capitani C, Courtney-Mustaphi CJ, Lane P, Prendergast ME, Stump D, de Cort G, Kaplan JO, Phelps L, Kay A, Olago D, Petek N, Platts PJ, Punwong P, Widgren M, WynneJones S, Ferro-Vázquez C, Benard J, Boivin N, Crowther A, CuníSanchez A, Deere NJ, Ekblom A, Farmer J, Finch J, Fuller D, Gaillard-Lemdahl MJ, Gillson L, Githumbi E, Kabora T, Kariuki R, Kinyanjui R, Kyazike E, Lang C, Lejju J, Morrison KD, Muiruri V, Mumbi C, Muthoni R, Muzuka A, Ndiema E, Kabonyi Nzabandora C, Onjala I, Schrijver AP, Rucina S, Shoemaker A, Thornton-Barnett S, van der Plas G, Watson EE, Williamson D, Wright D (2018) Drivers and trajectories of land cover change in East Africa: human and environmental interactions from 6000years ago to present. Earth Sci Rev 178:322-378. https://doi.org/10.1016/ j.earscirev.2017.12.010

Matlon PJ, Spencer DS (1984) Increasing food production in SubSaharan Africa: environmental problems and inadequate technological solutions. Am J Agric Econ 66:671-676. https://doi.org/10. 2307/1240976

Migot-Adholla S, Hazell P, Blarel B, Place F (1991) Indigenous land rights systems in sub-Saharan Africa: a constraint on productivity? World Bank Econ Rev 5:155-175. https://doi.org/10.1093/wber/5.1.155

Montgomery DR (2007) Soil erosion and agricultural sustainability. Proc Natl Acad Sci 104:13268-13272. https://doi.org/10.1073/pnas. 0611508104

Montgomery DR (2012) Dirt: the erosion of civilizations vol 3. University of California Press, Berkeley and Los Angeles, California

Moore TR (1979) Rainfall erosivity in East-Africa. Geogr Ann, Ser A 61: 147-156. https://doi.org/10.1080/04353676.1979.11879987

Morgan WB (1969) Peasant agriculture in tropical Africa. In Thomas, MF and Whittington, GW (eds): Environment and land use in Africa. Methuen \& Co, London. pp 241-272.

Morgan RPC (2005) Soil Erosion and conservation, vol 3. Blackwell Science Ltd, Oxford
Mung'ong'o CG, Loiske VM, Simon D, Spengen WV, Dixon C, Närman A (1995) Structural adjustment programmes and peasant responses in Tanzania. In: Simon D, Van Spengen W, Dixon C, Narman A (eds) Structurally adjusted Africa. Poverty, debt and basic needs. Pluto Press, London, pp 159-183

Myers N, Kent J (2001) Perverse subsidies: how tax dollars can undercut the environment and the economy. Island press, Washington, D.C.

Ngecu W, Mathu E (1999) The El-Nino-triggered landslides and their socioeconomic impact on Kenya. Environ Geol 38:277-284. https://doi.org/10.1007/s002540050425

Niamir-Fuller M (2000) The resilience of pastoral herding in Sahelian Africa. In: Berkes F, Folke C, Colding J (eds) Linking social and ecological systems: management practices and social mechanisms for building resilience. Cambridge University Press, Cambridge, pp 250-284

Nicholson SE (1996) A review of climate dynamics and climate variability in Eastern Africa. In: Johnson TC, Odada E, O. (eds) The limnology, climatology and paleoclimatology of the East African lakes. Gordon and Breach Publishers, Amsterdam. pp 25-56.

Nishigaki T, Sugihara S, Kilasara M, Funakawa S (2017) Surface runoff generation and soil loss under different soil and rainfall properties in the Uluguru Mountains, Tanzania. Land Degrad Dev 28:283-293. https://doi.org/10.1002/ldr.2499

Odgaard R (2002) Scrambling for land in Tanzania: processes of formalisation and legitimisation of land rights. Eur J Dev Res 14: 71-88. https://doi.org/10.1080/714000434

Oldeman LR (1992) Global extent of soil degradation. In: Bi-annual report 1991-1992/ISRIC. ISRIC, Wageningen. pp 19-36.

Ostrom E (2000) Collective action and the evolution of social norms. J Econ Perspect 14:137-158. https://doi.org/10.1257/jep.14.3.137

Ostrom E (2009) A general framework for analyzing sustainability of social-ecological systems. Science 325:419-422. https://doi.org/10. 1126/science.1172133

Pimentel D (2006) Soil erosion: a food and environmental threat. Environ Dev Sustain 8:119-137. https://doi.org/10.1007/s10668-005-1262-8

Pinckney TC, Kimuyu PK (1994) Land tenure reform in East Africa: good, bad or unimportant. J Afr Econ 3:1-28. https://doi.org/10. 1093/oxfordjournals.jae.a036794

Poesen J, Nachtergaele J, Verstraeten G, Valentin C (2003) Gully erosion and environmental change: importance and research needs. Catena 50:91-133. https://doi.org/10.1016/S0341-8162(02)00143-1

Pretty J (2003) Social capital and the collective management of resources. Science 302:1912-1914. https://doi.org/10.1126/science.1090847

Pretty JN, Noble AD, Bossio D, Dixon J, Hine RE, Penning de Vries FW, Morison JI (2006) Resource-conserving agriculture increases yields in developing countries. Environ Sci Technol 40:1114-1119. https:// doi.org/10.1021/es051670d

Rammel C, Stagl S, Wilfing H (2007) Managing complex adaptive systems - a co-evolutionary perspective on natural resource management. Ecol Econ 63:9-21. https://doi.org/10.1016/j.ecolecon. 2006.12.014

Reij C, Scoones I, Toulmin C (2013) Sustaining the soil: indigenous soil and water conservation in Africa. Routledge, London

Rodney W (1972) How europe underdeveloped africa. BogleL'Ouverture Publications, London

Roth EA (1996) Traditional pastoral strategies in a modern world: an example from northern Kenya. Hum Organ 55:219-224. https:// www.jstor.org/stable/44127165

Rufino MC, Thornton PK, Mutie I, Jones P, Van Wijk M, Herrero M (2013) Transitions in agro-pastoralist systems of East Africa: impacts on food security and poverty. Agric Ecosyst Environ 179: 215-230. https://doi.org/10.1016/j.agee.2013.08.019

Ruthenberg H (1968) Smallholder farming and smallholder development in Tanzania. Weltforum Verlag, München 
Ruthenberg H, Jahnke HE (1985) Innovation policy for small farmers in the tropics: the economics of technical innovations for agricultural development. Clarendon Press, Oxford. p 176

Ruttan LM, Borgerhoff Mulder M (1999) Are East African pastoralists truly conservationists? Curr Anthropol 40:621-652. https://doi.org/ $10.1086 / 300086$

Rutten MMEM (1992) Selling wealth to buy poverty: the process of the individualization of landownership among the Maasai pastoralists of Kajiado district, Kenya. Universiteit, Leiden, pp 1890-1990

Salami A, Kamara AB, Brixiova Z (2010) Smallholder agriculture in East Africa: trends, constraints and opportunities. African Development Bank, Tunis

Sandford G (1919) An administrative and political history of the Masai reserve. Waterlow \& Sons, London. pp 234.

Sendalo D (2009) A review of land tenure policy implications on pastoralism in Tanzania. Ministry of Livestock Development and Fisheries, Dar es Salaam

Smith CD (1989) Did colonialism capture the peasantry?: a case study of the Kagera District, Tanzania. vol 83. Scandinavian Institute of African Studies, Uppsala

Snyder KA (1996) Agrarian change and land-use strategies among Iraqw farmers in northern Tanzania. Hum Ecol 24:315-340. https://doi. org/10.1007/BF02169393

Sorrenson MPK (1968) Origins of European settlement in Kenya. Oxford University Press, Oxford

Spear T, Waller R (1993) Being Maasai: ethnicity and identity in East Africa. Ohio University Press, Athens

Stanley HM (1889) Through the dark continent: or, the sources of the Nile, around the Great Lakes of Equatorial Africa, and down the Livingstone River to the Atlantic Ocean. Low, Marston, Searle \& Rivington, London

Stump D (2010) "Ancient and backward or long-lived and sustainable?" The role of the past in debates concerning rural livelihoods and resource conservation in Eastern Africa. World Dev 38:12511262. https://doi.org/10.1016/j.worlddev.2010.02.007

Sullivan S, Rohde R (2002) On non-equilibrium in arid and semi-arid grazing systems. J Biogeogr 29:1595-1618. https://doi.org/10.1046/ j.1365-2699.2002.00799.x

Tengö M, Hammer M (2003) Management practices for building adaptive capacity: a case from northern Tanzania. In: Berkes F, Colding J, Folke C (eds) Navigating social-ecological systems: building resilience for complexity and change. Cambridge University Press, Cambridge, pp 116-132

Thompson J (1887) Through Masai land: a journey of exploration among the snowclad volcanic mountains and strange tribes of eastern equatorial Africa. Low, Marston, Searle, \& Rivington, London

Thornes JB (1990) Vegetation and erosion: processes and environments. Wiley, Chichester

Thornton RJ (1980) Space, time, and culture among the Iraqw of Tanzania. Academic Press, Cambridge

Throup D (1987) Economic \& social origins of Mau Mau 1945-53. James Currey, Melton

Tiffen M, Mortimore M, Gichuki F (1994) More people, less erosion: environmental recovery in Kenya. John Wiley \& Sons Ltd, Chichester
Tittonell P, Giller KE (2013) When yield gaps are poverty traps: the paradigm of ecological intensification in African smallholder agriculture. Field Crop Res 143:76-90. https://doi.org/10.1016/j.fcr. 2012.10.007

Tosh J (1973) Colonial chiefs in a stateless society: a case-study from northern Uganda. J Afr Hist 14:473-490. https://doi.org/10.1017/ S0021853700012834

Trærup SL, Mertz O (2011) Rainfall variability and household coping strategies in northern Tanzania: a motivation for district-level strategies. Reg Environ Chang 11:471-481. https://doi.org/10.1007/ s10113-010-0156-y

Trapnell C, Griffiths J (1960) The rainfall-altitude relation and its ecological significance in Kenya. E Afr Agr Forestry J 25:207-213. https:// doi.org/10.1080/03670074.1960.11665266

Trewartha GT, Zelinsky W (1954) The population geography of Belgian Africa. Ann Assoc Am Geogr 44:163-193

Turner BL, Hydén G, Kates RW (1993) Population growth and agricultural change in Africa. University Press of Florida, Gainesville

UNDESA (2017) Population division - World Population Prospects. Retrieved from https://www.population.un.org/wpp. Accessed 08 April 2018

Vanmaercke M, Poesen J, Broeckx J, Nyssen J (2014) Sediment yield in Africa. Earth Sci Rev 136:350-368. https://doi.org/10.1016/j. earscirev.2014.06.004

Walling DE, Webb BW (1996) Erosion and sediment yield: global and regional perspectives. International Association of Hydrological Sciences, Wallingford

Warren A (1995) Changing understandings of African pastoralism and the nature of environmental paradigms. Trans Inst Br Geogr 20:193203. https://doi.org/10.2307/622431

Western D, Groom R, Worden J (2009) The impact of subdivision and sedentarization of pastoral lands on wildlife in an African savanna ecosystem. Biol Conserv 142:2538-2546. https://doi.org/10.1016/j. biocon.2009.05.025

Widgren M, Sutton JE (1999) 'Islands' of intensive agriculture in the East African Rift and highlands: a 500-year perspective. Departments of Human and Physical Geography, University of Stockholm, Stockholm

Wilson G (2012) Community resilience and environmental transitions vol 1. Routledge, London

Wynants M, Solomon H, Ndakidemi P, Blake WH (2018) Pinpointing areas of increased soil erosion risk following land cover change in the Lake Manyara catchment, Tanzania. Int J Appl Earth Obs Geoinf 71:1-8. https://doi.org/10.1016/j.jag.2018.05.008

Publisher's note Springer Nature remains neutral with regard to jurisdictional claims in published maps and institutional affiliations. 